\title{
Lesson study and 21st-century skills: Pre-service Teachers Reason, Produce and Share
}

\author{
Sabahattin Yeşilçınar* \\ Department of English Language Teaching, Muş Alparslan University, Muş, Turkey \\ Orcid: 0000-0001-6457-0211
}

\author{
Ahmet Aykan \\ Department of Curriculum and Instruction, Muş Alparslan University, Muş, Turkey \\ Orcid: 0000-0002-8033-0821
}

\begin{tabular}{|c|c|}
\hline Article history & Being a collaborative professional development model and contributing \\
\hline $\begin{array}{l}\text { Received: } \\
24.05 .2021\end{array}$ & $\begin{array}{l}\text { to the collaboration and communication skills of the group members, } \\
\text { lesson study was coined in Japan and has been applied in many countries }\end{array}$ \\
\hline $\begin{array}{l}\text { Received in revised form: } \\
03.01 .2021\end{array}$ & $\begin{array}{l}\text { since then, which supports and enhances the professional development } \\
\text { of teachers or pre-service teachers. Although literature abounds in } \\
\text { studies on lesson study or on } 21 \text { st-century skills, there is no study }\end{array}$ \\
\hline $\begin{array}{l}\text { Accepted: } \\
05.01 .2022\end{array}$ & $\begin{array}{l}\text { examining the impact of lesson study on } 4 \text { Cs. Therefore, adopting an } \\
\text { intrinsic case study approach, this paper examined to what extent a lesson }\end{array}$ \\
\hline Key words: & study implementation influenced pre-service teachers' 21 st-century \\
\hline $\begin{array}{l}\text { Lesson study; professional } \\
\text { development; } 21 \text { st-century } \\
\text { skills; practicum }\end{array}$ & $\begin{array}{l}\text { skills in the Turkish context where lesson study is not an embedded } \\
\text { tradition. Participants were six senior students of English language } \\
\text { teaching. The data generated were wide-ranging: recordings of meetings, } \\
\text { teachers' in-class observation notes, 4Cs checklist, recorded pre- and } \\
\text { post-interviews, lesson study observation forms, and post-lesson } \\
\text { evaluation forms. Findings showed that } 21 \text { st-century skills of pre- } \\
\text { service teachers were developed, and pre-service teachers started to } \\
\text { REASON the issues they face in the classroom, PRODUCE alternative } \\
\text { way(s) to overcome troubles or support learning, and SHARE their } \\
\text { experiences and solutions with colleagues sincerely in a collaborative } \\
\text { atmosphere. However, one intriguing finding is that, in a context which } \\
\text { does not embed lesson study, if the process is not internalized, it may } \\
\text { cause the future teachers to be loath to reason, produce and share due to } \\
\text { the lack of self-efficacy as well as the fear of being criticized. }\end{array}$ \\
\hline
\end{tabular}

\section{Introduction}

Within the scope of 21 st-century skills, each education system aims to train individuals who can collaborate and communicate appropriately as well as think critically and creatively (Greenhill, 2010). This points out the vital role of teacher training programmes because they are supposed to prepare pre-service teachers with the required knowledge and skills. The results of exams such as PISA and TIMSS bring the education systems of the countries in the first place to the fore. Considering the exam results of PISA 2015, East Asian countries (Singapore, Japan, South Korea, China) are at the top in the categories of mathematics, science and reading

\footnotetext{
*Correspondency: sycinar@yahoo.com
} 
skills (OECD, 2015). Therefore, research has focused on the education systems of these countries (TIMSS, 2015). Researchers consider the lesson study model as the reason why these countries are at the top in the list of PISA and TIMSS (Aykan \& Dursun, 2021). Although the collaborative and communication-based environment offered by the lesson study model can contribute to both critical and creative thinking skills of pre-service teachers, there is not such a professional development model in Turkey's education system. Therefore, this study implemented a lesson study model in the process of training pre-service teachers, focusing on learning and innovation skills which consist of collaboration, communication, creativity, and critical thinking (4Cs) skills. There is no research directly examining the impact of lesson study on 21-century skills of teachers or pre-service teachers, although studies have displayed the relationship between lesson study and critical thinking (Angeline \& Alvarez, 2018; Obara \& Bikai, 2019; Villalon, 2016), creativity (Aykan, 2019; Chassels \& Melville, 2009; Gonzalez \& Deal, 2019), collaboration (Chassels \& Melville, 2009; Murata \& Pothen, 2011; Samaranayake, Premadasa, Amarasinghe, \& Paneru, 2018; Skott \& Moller, 2017), and communication (Estrella, Zakaryan, Olfos, \& Mathilde 2020; Ong, Lim, \& Ghazali, 2013). Although this paper specifically investigates the effect of lesson study approaches on 21 st-century skills, a theoretical perspective guiding it has its basis in both 21 st-century skills as well as in sociocultural theory (Vygotsky, 1978).

\section{Lesson study model and zone of proximal development (ZPD)}

Sociocultural theory defines learning as a sociological process of engagement in a community. From this perspective, the source of learning is found in social interaction (Vygotsky, 1978). In other words, the social interaction between individuals with different levels of skills and knowledge is the sine qua non for the effective learning. Thus, the students are expected to bridge the gap between theory and practice through jointly constructed learning communities (Frykholm, 1998). As one of the research questions of the current paper deals with pre-service teachers' collaboration and communication skills, a sociocultural perspective provides a valuable lens for examining the impact of lesson study on their stated skills. In particular, Vygotsky's zone of proximal development (ZPD) was of interest as it focusses on what the individual can do with and without guidance.

Sociocultural theories advocate that the interactions of individuals with other people or artifacts in their community contribute to the individual learning and development (Vygotsky, 1978). Therefore, it is useful to benefit from social-cultural theories while explaining the development of English as a foreign language (EFL) pre-service teacher during lesson study process. Purwanti and Hatmanto (2019) interviewed English teachers to examine their views about lesson study from the lens of Vygotskian sociocultural theory. They found that teachers developed their teaching capacity, especially regarding English language knowledge, teaching pedagogy, and teaching innovation. Using Vygotskian sociocultural theory and culturalhistorical activity theory as theoretical frameworks, Tasker (2014) investigated EFL teacher professional development through lesson study. He concluded that lesson study has potential to provide teachers with an effective conceptual tool to mediate their learning, and that sociocultural theory provides English language teaching (ELT) teachers with a theoretical basis for understanding how they learn through participation in lesson study.

\section{Lesson study model and 21st-century skills}

Lesson study, which was coined in Japan and has been applied in many countries since then, supports and enhances the professional development of teachers or pre-service teachers 
(Aykan, 2019; Stigler \& Hiebert, 2016). In lesson study, pre-service teachers choose a topic and prepare a plan in collaboration. One pre-service teacher performs the lesson while others do observation. Then, they discuss their observations and finally revise the lesson plan. Thus, group members can see all the steps related to planning and implementing a lesson in detail. Lesson study is a collaborative professional development model and contributes to the collaboration and communication skills of the group members (Aykan, 2019). Thus, applying it to instruction affects the students' creativity and critical thinking skills (Asyari, Al Muhdhar, \& Susilo 2016). Therefore, this paper examined the relationships between lesson study and 21 st-century skills. These skills are categorized as: learning and innovation skills; information, media, and technology skills; and life and career skills (Partnership for 21st Century Skills, 2009).

Angeline and Alvarez (2018) conducted a study with 12 pre-service teachers and emphasized the effect of lesson study on pre-service teachers' reflective thinking and self-assessment skills. Besides, Villalon (2016) found that lesson study improved self-confidence and openmindedness of pre-service teachers, while Obara and Bikai (2019) emphasized the contribution of lesson study to in-service teachers' skills such as negotiating different views and active learning. Focusing on the creativity skills of teachers, Gonzalez and Deal (2019) observed that lesson study could enable teachers to perform more innovative and creative works in collaboration. Chassels and Melville (2009) carried out their study with 60 pre-service teachers and concluded that lesson study helped participants to develop their analysis, synthesis, and evaluation skills. On the other hand, Lamb (2015) found that pre-service teachers produced more creative practices, gained risk-taking behaviors, and created original ideas during the lesson study process. The participants of Aykan (2019) stated that the implementation of lesson study created a friendly environment which resulted in more enjoyable lessons.

Research provides evidence that lesson study (1) creates a collaborative working environment by fostering harmonious relationship within the group members, (2) helps develop positive attitudes and beliefs towards collaboration by taking teamwork and joint responsibility, and (3) enables pre-service teachers to socialize professionally (Chassels \& Melville, 2009; Murata \& Pothen, 2011; Samaranayake et al., 2018; Skott \& Moller, 2017). On the other hand, while Estrella et al. (2020) advocated that teachers' communication skills could be developed through lesson study, Ong, Lim, and Ghazali (2013) concluded that lesson study provides effective participation and mutual feedback to teachers and thus improves the verbal communication skills of teachers.

\section{Research questions}

Considering the need for the introduction of lesson study into countries where it is not an embedded tradition (Stigler and Hiebert 2016), it is worth investigating the practicality of and impact of lesson study on 21st-century skills of ELT pre-service teachers in Turkey. The implementation of lesson study may bring significant opportunities in terms of learning and applying 21st-century skills. The cyclical process of the model offers a collaborative and communicative environment so that pre-service teachers can criticize other group members' ideas and suggestions critically and therefore create innovative ideas. Although literature abounds in studies on lesson study or on 21 st-century skills, there is no study examining the impact of lesson study on 4Cs. In this context, the following research questions are prepared:

(1) What is the impact of lesson study on ELT pre-service teachers' critical thinking?

(2) What is the impact of lesson study on ELT pre-service teachers' creativity? 
(3) What is the impact of lesson study on ELT pre-service teachers' collaboration and communication?

\section{Method}

\section{Research Design}

This study adopted an intrinsic case study approach to investigate the impact of lesson study on EFL pre-service teachers' 4Cs. The intrinsic case study approach is advised for research which aims at delving into and better understanding a particular case (Mills, Durepos, \& Wiebe, 2010). In a case study, the purpose is the curiosity in the case itself but not theory building, and the case itself is of interest. The current study may be considered as an intrinsic case study as its primary goal was to examine the role of lesson study in EFL pre-service teachers' 21 st-century skills. The consensus is that interpretivist research does not care about making statistical generalizations (Onwuegbuzie \& Leech, 2010) but aims to obtain insights into certain educational and social processes that exist within a specific context. Although generalization is not possible due to the small sample size, this study provided detailed information about the procedure, participants, and research context to ensure the transferability of the findings to different environments (Onwuegbuzie \& Leech, 2010).

\section{Participants}

To recruit the participants who were potential to give resourceful information, the researchers used purposive sampling for achieving the goals of the study (Patton, 2002). The researchers determined some criteria for recruiting participants: being an ELT senior student, attending and being interested in the lessons, and having a GPA between 2.0 and 3.0 on a 4.0 scale. Based on these criteria, 10 volunteers were recruited. Then, they were informed about the research process and asked to sign a consent form. After the pilot study, four participants dropped out of the study due to various reasons; thus, the study was finalized with six EFL preservice teachers (four females; two males) studying in a Turkish state university during the 2019-2020 academic year, as part of Teaching Practicum courses. These criteria were considered to help participants (1) be familiar with lesson study, (2) be able to share their experiences, (3) express their views about the implementation of lesson study, (and 4) how it contributed to their 21 st-century skills. The average age was approximately 22 years. In presenting the findings, participants' names were changed to maintain anonymity.

\section{Research context and procedure}

In Turkey, English language teachers must complete a 4-year undergraduate programme. In the final year, pre-service teachers need to attend primary or secondary schools within the scope of the Teaching Practicum courses which generally consist of two phases: School Experience (first semester) and Teaching Practice (second semester). The former aims to help pre-service teachers become familiar with the teaching profession through real classroom situations under the supervision of the mentor teacher and obtain the required cognitive level before starting to practice in the actual classroom. The latter aims to enable preservice teachers to perform teaching tasks in real classroom situations on their weekly visits under the supervision of the mentor teacher, to obtain teaching qualifications to act as a teacher, to prepare lesson plans and conduct lessons in accordance with the education system. Prior to practicum, pre-service teachers are provided microteaching simulations in various pedagogy courses (e.g., ELT Methodology, Approaches, and Methods in Language Teaching), which help them apply pedagogical theories in realistic teaching situations. However, considering either 
teaching practicum courses or microteachings, pre-service teachers often perform their tasks individually and neglect the 21st-century skills (in particular, 4Cs). For example, although Turkey emphasizes the importance of training teachers with 21st-century skills in the 2018 educational reform, this goal remains in theory (Hamarat, 2019), which also affects teacher training programmes. In the current system, pre-service teachers mostly demonstrate their teaching performance individually. Therefore, the researchers implemented lesson study in teaching practicum course as it includes 21 st-century skills such as collaboration, communication, creativity, and critical thinking.

The researchers decided to implement a lesson study in teaching practice (second semester). As participant observers, the researchers both participated in the lesson study cycles and noted their observations. The teaching practice lasted for 9 weeks (see Table 1 for the plan and content of the lesson study cycle). The researchers provided information about the lesson study process, drawing on Stigler and Hiebert (2009). Besides, participants watched a recorded lesson study video in the second week so that the participants could better understand the nature of the process. In the third week, to ensure that all participants were ready to implement the lesson study model, a sample cycle was piloted. In the same week, semi-structured interviews were conducted, and participants were asked to predict the possible contributions of lesson study cycles on their 4Cs skills at the end of the process. Within the following weeks (fourth-ninth weeks), six applications were demonstrated. All participants used the Lesson Study Observation Form during the applications, while Post-Lesson Evaluation Form was applied after each application. Finally, semi-structured interviews were used to determine the contributions of lesson study cycles to pre-service teachers' 4Cs. In order for each of the six pre-service teachers to practice in the lesson study cycle, three cycles of six weeks were designed. Each cycle was completed in two weeks. For example, in the 4th week (cycle 1), preservice teachers created the lesson plan collaboratively. The lesson plan was performed in the classroom by one of the group members. Other group members observed this lesson and took notes. In the 5th week, a research lesson was conducted, and the lesson plan was revised in line with the opinions and suggestions of the pre-service teachers. The revised lesson plan was implemented in the classroom by a different group member. The other two cycles were completed following the same procedure of cycle 1 .

Table 1. Procedure of the study

\begin{tabular}{|c|c|c|}
\hline Week & Action & Time \\
\hline 1 & Introducing the lesson study & 90 minutes \\
\hline 2 & Introducing lesson study \& Watching a recorded lesson study video & 90 minutes \\
\hline \multirow[t]{3}{*}{3} & Piloting & 135 minutes \\
\hline & Conducting semi-structured interviews & 55 minutes \\
\hline & 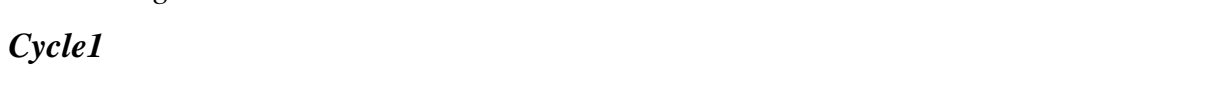 & $\begin{array}{l}180 \text { minutes } \\
\text { (per week) }\end{array}$ \\
\hline \multirow[t]{3}{*}{4} & Collaborative design of the lesson plan & \\
\hline & Implementation of the lesson plan by a group member & \\
\hline & Observation and note-taking by other group members & \\
\hline \multirow[t]{4}{*}{5} & $\begin{array}{l}\text { Meeting of all pre-service teachers to discuss and evaluate their observations under the } \\
\text { guidance of researchers }\end{array}$ & \\
\hline & Recording of meeting \& Generating a new lesson plan & \\
\hline & Implementation of the lesson plan by a different group member & \\
\hline & Cycle 2 & $\begin{array}{l}180 \text { minutes } \\
\text { (per week) }\end{array}$ \\
\hline 6 & $\begin{array}{l}\text { Collaborative design of the first lesson } \\
\text { Implementation of the lesson plan by a group member } \\
\text { Observation and note-taking by other group members }\end{array}$ & \\
\hline
\end{tabular}


Meeting of all pre-service teachers to discuss and evaluate their observations under the guidance of researchers

Recording of meeting\& Generating a new lesson plan

Implementation of the lesson plan by a different group member

Cycle3

180 minutes

(per week)

Collaborative design of the first lesson

Implementation of the lesson plan by a group member Observation and note-taking by other group members

Meeting of all pre-service teachers to discuss and evaluate their observations under the guidance of researchers

Recording of meeting \& Generating a new lesson plan

Implementation of the lesson plan by a different group member

Semi-structured interviews

82 minutes

\section{Data collection and analysis}

The data generated were wide-ranging: recordings of meetings, teachers' in-class observation notes, 4Cs checklist, and recorded pre- and post-semi-structured interviews with pre-service teachers, including lesson study observation forms and post-lesson evaluation forms. The researchers developed the checklist (Appendix 1) based the literature (Partnership for 21st Century Learning, 2015), considering the recommendations of Kutlu et al. (2014). In this context, a systematic process has been followed. First, the purpose of the checklist tool was determined, and determining pre-service teachers' teaching performance was considered the main objective. Then, the literature was reviewed to identify the criteria. After determining the criteria, two academicians who were experts in measuring the relevant performance prepared the draft version of the checklist. A draft form was sent to three field experts to collect evidence for content validity. Based on their feedback, the checklist was found appropriate in measuring the relevant structure. Besides, the researchers used observation forms that were prepared and used by the second author. The researchers observed participants' applications and discussions, and they filled a weighted 4Cs checklist so that they could monitor the development in participants' 4Cs skills. Pre-service teachers wrote down all the salient changes on the observation form per week and these changes were discussed through a post-lesson evaluation form. The data obtained from these forms and the 4Cs checklist also displayed whether there was a mismatch between pre-service teachers' performance and their opinions about the contributions of lesson study cycles.

Principal data sources were transcripts of interviews and planning/evaluation meetings. Before collecting the data, the interview protocol was reviewed for accuracy and then piloted. The interviews took place in the researchers' office and were recorded. The total duration of the interviews was 82 minutes. Although the data were analysed via Nvivo, the researchers initially analysed the qualitative data manually as a piloting process (Welsh, 2002) so that the researchers could take precautions for data loss. Content analysis was used, which means that all categories were determined while analysing the transcripts. After transcribing the interviews, the researchers examined and categorized the data independently. As the focus was on the impact of the lesson study process on $4 \mathrm{Cs}$, a deductive mode of data analysis was adopted while determining the themes:

(1) Critical thinking,

(2) Creativity, and

(3) Collaboration \& Communication

At the end of the study, researchers interviewed with pre-service teachers to elicit their accounts about whether lesson study developed their 4Cs skills. Since researchers committed to 
developing understanding based on the ideas and terms stated by participants, an informant style of interviewing (Powney \& Watts, 1987) was chosen for exploring participant perspectives. Researchers focused entirely on the performance of the participants as they have not previously been together in any context. While evaluating the participants, the names were closed and evaluated separately by both researchers. The interviews were coded independently by the researchers.

\section{Findings}

The current study examined the impact of lesson study on 21 st-century skills of preservice teachers of English language teaching. Findings displayed that the lesson study made positive contributions to their 21 st-century skills considering critical thinking, creativity, communication, and collaboration. A carefully conducted coding process advocated that lesson study help pre-service teachers REASON the issues they face in the classroom, PRODUCE alternative way(s) as well as method(s) to overcome trouble or support students' learning and SHARE their experience and the solution or development they found with their colleagues in a sincere and collaborative atmosphere. The acronyms (REASON, PRODUCE, and SHARE) emerged from the initial letters of related codes that were created based on pre-service teachers' opinions (please see Table 2).

Table 2. Pre-service teachers' opinions on the impact of the lesson study.

\begin{tabular}{|c|c|c|}
\hline Themes & Codes* & $\mathrm{f} * *$ \\
\hline \multirow{6}{*}{ 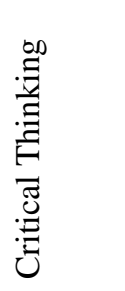 } & Reflection/ reflective learning & 15 \\
\hline & Evaluation and decision making & 13 \\
\hline & Active learning & 12 \\
\hline & Self-awareness for accurate judgment/self-confidence & 10 \\
\hline & Open-mindedness & 8 \\
\hline & Negotiating different views & 11 \\
\hline \multirow{8}{*}{ 离 } & Processing, analysing, synthesizing ideas & 7 \\
\hline & Risk-taking & 8 \\
\hline & Originality/original ideas & 12 \\
\hline & Divergent thinking & 11 \\
\hline & Usefulness & 13 \\
\hline & Creative thinking & 15 \\
\hline & Enjoyment & 10 \\
\hline & Socialization \& social interdependence & 8 \\
\hline \multirow{4}{*}{ 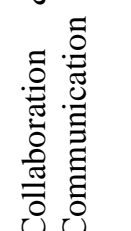 } & Harmonious relationship (within the group members) & 12 \\
\hline & Assuming shared responsibility for teamwork & 13 \\
\hline & Reciprocal feedback & 7 \\
\hline & Effective participation & 15 \\
\hline
\end{tabular}

*Codes were not presented according to frequencies in order to show how acronyms emerged.

**Since participants expressed more than one opinion for different codes, grand total increased more than the overall total number of teachers.

The findings were presented below with respect to research questions. 


\section{The impact of lesson study on pre-service teachers' critical thinking}

Pre-service teachers pointed out the strong resemblance between the principles of lesson study and critical thinking, stating that critical thinking includes thinking, planning, acting, and reflecting (evaluating). After experiencing the lesson study process, they gained the ability to think about or reflect on their performance and started to question the quality of their actions so that they could perform it differently next time. Besides, the process requires pre-service teachers' active engagement in activities during the whole process.

This process helped us to think about our demonstrations. I and other friends shared our ideas sincerely. We considered the suggestions of each friend and tried to make new decisions with these recommendations. (Yusuf)

I learned how to revise a lesson plan based on students' interests and abilities. In addition, while preparing the plan, I learned about multi-faceted evaluation (process and product) and thus making healthy decisions in this process. Thereupon, the application process of the model offered me and my friends the opportunity to observe and improve our teaching activities. (Asmin)

In this process, we had an idea about how to put theory into practice. Besides, using the collaborative learning method and trying to apply it to students helped us to be more active learners. (Fatma)

Pre-service teachers indicated self-awareness as a salient characteristic they obtained. That is, they thought about, evaluated, and interrogated their point of view and found out the evidence used to support. Their statements also brought open-mindedness to the fore. They were observed to seek new proof or points of view when the current proof was inadequate or contentious and be willing to revise their views if the evidence assured them. Thus, they formed a habit of negotiating and respecting different views. Here are some opinions:

I was the first to perform a lesson. I made a mistake but never noticed it throughout the instruction. I forgot to give feedback to students and always neglected to include children in the evaluation process of activities. I realized that we include the students who are always at the front of the class, and we do not notice the students who need to be evaluated. I became aware of this fact not when I was teaching, but when observing my friends. (Adem) I didn't want to be criticized before lesson study. Now, I feel flexible and open-minded during my peers' feedback. (Sibel)

I had no such knowledge before, this would be an experience for me, and I can apply it in my future professional life. I also form the habit of respecting others' opinions. (Elif)

\section{The impact of lesson study on pre-service teachers' creativity}

The consensus was that the meetings conducted immediately after observations under the guidance of researchers resulted in original ideas. Pre-service teachers were required to reflect on the demonstrations. That is, six different individuals debated on and evaluated the performance, which forms a basis for divergent thinking. Lesson study let pre-service teachers observe different learning with multiple eyes. Besides, pre-service teachers were willing to take risks and gained the ability to accept and learn from mistakes during the lesson study process. Here are some representative excerpts:

We met and discussed different ideas and suggestions. We have created a new lesson plan by analysing and synthesizing opinions and suggestions. (Asmin). 
I think lesson study is a good example of risk-taking culture because we could prepare a lesson plan involving new and different methods and techniques that seem otherwise impossible to be applied. (Sibel)

We had friends who thought differently and came up with new ideas. We learned a lot from them. Such various new thoughts and discussions usually resulted in original ideas. (Yusuf)

When pre-service teachers could manage divergent thoughts and present original ideas, they observed that the lesson plans became more useful. The more they tried to produce original and useful lesson plans, the more their creativity increased. This made pre-service teachers enjoy the cycles they experienced.

Considering activities, puzzles, questions, and answers, we learn which one should be used in the lesson. For example, we recognized what kind of applications could be utilized in crowded classrooms. (Elif)

Lesson study is a useful model because it helped me see the mistakes that occurred during the teaching process, identify the trouble, and compensate it owing to different evaluations. (Adem)

Thanks to the collaboration, we did not adopt a ready lesson plan. Instead, we used our creativity; thus, we created original lesson plans. (Sibel)

Obviously, we had a little difficulty in the first applications, but as I gained experience, it became easier and more enjoyable. (Fatma)

\section{The impact of lesson study on pre-service teachers' collaboration and communication skills}

In lesson study, pre-service teachers collaborated meaningfully in the course and interacted with each other to share and co-construct their knowledge. Lesson study provides reasons for the teachers to appreciate each other's presence in the post-lesson meetings in which collective learning is a socialization process. In a social instructional environment, pre-service teachers are active in lesson study cycles as a part of teamwork and give sincere feedbacks to each other as a result of harmonious relationships.

Lesson study contributes to our socialization as it is a collaborative model. I learn more based on my interactions with other peers. (Sibel)

A few people come together to implement a plan and work to optimize it. Everyone reveals their own thoughts, and they try to blend it and make it the best plan. Thus, we can see more lesson plans and more thoughts, which help us to apply different lesson plans for creating the best one. (Yusuf)

In our group, there were six people: therefore, six different views and six different plans. This requires a shared responsibility among the group members. This provides a crucial advantage in terms of developing a lesson plan. (Asmin)

The collaborative nature of the lesson study provided the teachers with opportunities to engage in a shared environment of providing and sharing constructive support and feedback to others during post-lesson planning/evaluation meetings. This also affected the way pre-service teachers communicate, resulting in multi-way communication. 
While applying lesson study, we paid attention to the ideas of our friends and also to give feedback. Everyone evaluated the thoughts of the group members and synthesized them together with their own thoughts. (Fatma)

I think lesson study provides effective participation because when you are conducting a lesson, other friends take notes and find shortcomings for creating a more effective lesson plan. (Elif)

\section{Discussion}

The findings were presented below with respect to research questions.

\section{Contribution of lesson study to pre-service teachers' critical thinking: Teacher REASON}

Lesson study can be a positive contributor in terms of critical thinking. This finding confirms various studies advocating that lesson study improves the critical thinking skills of pre- or in-service teachers (Angeline \& Alvarez, 2018; Obara \& Bikai, 2019; Villalon, 2016). The consensus that interviewees reached is the fact that pre-service teachers gain the ability of reasoning. They stated that lesson study helps pre-service teachers gain features that critical thinkers should have, such as being open-minded which requires negotiating different views, knowing how to reflect on their and/or their friends' teaching, having self-awareness for accurate judgment and self-confidence, being an active learner throughout the instructional process, and being able to evaluate and make decisions. In the same vein, some studies emphasized the contribution of lesson study to participants' reflective thinking and selfassessment skills (Angeline \& Alvarez, 2018), active learning skills as well as their skills of negotiating different views (Obara \& Bikai, 2019), and self-confidence and open-mindedness skills (Villalon, 2016).

Another important side of the lesson study is that pre-service teachers' self-efficacy develops since they receive feedback from others on their performance. Considering self-efficacy (Bandura, 1977), receiving positive feedback from the people around regarding their works helps individuals to feel more successful in their works. The positive reinforcements of other group members during the process of lesson study also help pre-service teachers feel more professionally successful and competent, which is also supported by Aykan and Dursun (2021). The collaborative work environment (which is not common in the Turkish education setting) created by the lesson study contributes to and enhances critical thinking skills (REASON) of pre-service teachers. This finding is remarkable because unlike the rote-learning based education system in Turkey, pre-service teachers become critical and reasoning thinkers.

\section{Contribution of lesson study to pre-service teachers' creativity: Teacher PRODUCE}

The findings underlined that lesson study contributed positively to 21 st-century skills, specifically the creative thinking skills of pre-service teachers. Literature abounds in studies claiming that lesson study improves the creative thinking skills of pre- and in-service teachers (Aykan, 2019; Chassels \& Melville, 2009; González \& Deal, 2019; Lamb, 2015). As highlighted in this study, research claims that lesson study helps participants pre-service teachers produce more creative practices and gain risk-taking behaviours (Lamb, 2015), create original ideas (Lewis, 2000). It is also considered to have affirmative impacts on their divergent thinking skills (Murata \& Pothen, 2011). Lewis (2000) stated that teachers created their own unique lesson plans; therefore, they came up with original ideas during the lesson study process. 
He underlined that this process also improved the creativity of teachers who could design original lessons. In the Turkish context, Aykan (2019) mentioned that pre-service teachers started to enjoy the model as they gained experience. Similarly, the current study displays that although pre-service teachers were shy and thus unwilling to join the discussions in the first applications of the model, they became more willing and happier after experiencing the lesson study process. From this point of view, since lesson study brings together pre- and in-service teachers with different knowledge and experience, it is thought to improve their creativity (PRODUCE) such as processing, analysing, synthesizing ideas; taking risks on different ideas and suggestions; generating original ideas; adopting a sense of thinking differently, and thinking creatively. In Turkey, teachers usually adopt and/or adapt the ready lesson plans with a 'one size fits all' logic, which harms creativity. However, with the lesson study process, the participants who collaborated (to create a lesson plan, observe their friends and evaluate the lesson plan) started to create a new product (lesson plan). Those who worked together to generate an original product also had the opportunity to share their creative ideas.

\section{Contribution of lesson study to pre-service teachers' collaboration and communication skills: Teacher SHARE}

The last research question examined whether the lesson study positively developed the collaboration and communication skills of pre-service teachers. The lesson study was found to affect participants' collaboration and communication skills. For example, this model constituted a social instructional environment where pre-service teachers participate in all lesson study cycles effectively as a part of teamwork and give sincere feedback to each other as a result of harmonious relationships. These findings confirm various studies (Chassels \& Melville, 2009; Estrella et al. 2020; Murata \& Pothen, 2011; Ong et al. 2013; Samaranayake et al. 2018; Skott \& Moller, 2017). Lesson study is a crucial professional development model which helps student socialize and spend time with group members, share common responsibilities in teamwork, and give appropriate feedback to their peers (Chassels \& Melville, 2009; Murata \& Pothen, 2011). They participate in activities and teamwork effectively.

The collaborative side of the lesson study is similar to the basic understanding of the Zone of Proximal Development (ZPD) of Vygotsky (1978) who emphasizes the socio-cultural dimension of learning. The lesson study process enables pre-service teachers to reveal their own potential as they work with both their peers and the experts of the subject. The development in these skills of pre-service teachers may be owing to the fact that lesson study encourages focusing more on the lesson plan and its implementation. Therefore, pre-service teachers contribute to the process in a more comfortable environment when they learn that their personalities and practices are not criticized. Tasker (2014) concluded that lesson study has potential to provide EFL teachers with an effective conceptual tool to mediate their learning, and that sociocultural theory provides ELT teachers with a theoretical basis for understanding how they learn through participation in lesson study.

Research indicates that each teacher has a common responsibility for the group in teamwork, which would develop the teachers' common commitment skills for the team within the scope of collaborative learning (Chassels \& Melville, 2009; Murata \& Pothen, 2011; Ong et al., 2013). However, this situation is different in a competition based Turkish education system. Preservice teachers demonstrate their microteachings individually and do their best to get high marks. This creates a hidden competition among pre-service teachers. At that point, implementing lesson study into teacher training programmes in Turkey will not only change the traditional competitive ways of instruction but also contributes to training future teachers 
who are willing to SHARE their knowledge and experiences.

\section{Conclusion and Suggestions}

This paper aimed to determine the relationship between lesson study and 21 st-century skills as the implementation of the model is considered strongly to support the communication and collaboration among the students and provide the participants with the opportunity to think critically and creatively. As a result, lesson study was found to contribute positively to preservice teachers' 21 st-century skills, reinforcing the idea that lesson study can enable teacher training programmes to train teachers who REASON, PRODUCE, and SHARE.

Pre-service teachers gained the ability of consciously making sense of things, using logic, and adapting practices based on new or existing information. They exhibited a questioning manner during the whole process, including preparing, observing, and reflecting on a lesson plan with other group members. This is because a collaborative working environment helps teachers learn from each other (Öztürk \& Aydın, 2019). Therefore, pre-service teachers who think reflectively, express their thoughts openly, actively participate in the process and thus gain selfconfidence can develop their critical thinking skills. As soon as pre-service teachers acquired the capacity of reasoning for a better lesson plan, they tried to generate new and different ideas during the implementation of the model. Using their creativity at every stage of this process, pre-service teachers became active producers of their lesson plans. The more they tried to produce original and different ideas and took risks, the more they had the opportunity to develop their creativity. In the lesson study process, the pre-service teachers shared the common responsibility as a team and worked in harmony by communicating appropriately with other friends and by providing immediate feedback. Not only did they adopt their friends' suggestions, but also they shared their thoughts sincerely.

The lesson study model both developed critical thinking skills and creativity of pre-service teachers and positively contributed to their collaboration and communication skills. Accordingly, the lesson study was found useful in training pre-service teachers who reason, produce and share. The model is believed to be a professional development model that can make a significant contribution to efforts to train more qualified teachers. Thus, it may be crucial to implement the lesson study model in teacher education, especially in English language teaching programmes. Although time constraint is the main concern in studies on lesson study (Lampley, Gardner, \& Barlow, 2018), this was not the case in the current study. For example, each lesson study required 180 minutes (4 lessons) per week, while teaching the practicum course provides 270 minutes (6 lessons) in Turkey. In this context, implementing lesson study into teaching practicum courses will not only constitute a new professional development understanding but also contribute to the quality of education since the current education system suffers from the gap between theory and practice.

This study has some limitations. First, the participants were pre-service teachers. However, the collaboration of pre-service teachers with in-service teachers in a lesson study model may provide more information. In doing so, further research will report whether the effects of lesson study are the same or different in terms of pre- and in-service teachers. The second limitation is the design of the study. Although studies on lesson study are mostly qualitative in nature, future research can adopt an experimental design in order to examine the effect rate of lesson study on professional development. 


\section{References}

Armstrong, A. (2011). Lesson study puts a collaborative lens on student learning. Tools for Schools, 14(4), 1-8. Retrieved from https://learningforward.org/wpcontent/uploads/2011/06/summer-2011-tool.pdf

Asyari, M. Al Muhdhar, M. H. I., \& Susilo, H. (2016). Improving critical thinking skills through the integration of problem based learning and group investigation. International Journal for Lesson and Learning Studies, 5(1), 36-44. doi: 10.1108/IJLLS-10-2014-0042

Aykan, A. (2019). Öğretmen adayları açısından ders araştırması modelinin mesleki gelişim kapsaminda incelenmesi [Investigating lesson study model within the scope of professional development in terms of pre-service teachers]. (Unpublished doctoral dissertation). Gaziosmanpaşa University, Tokat.

Aykan, A. \& Dursun, F. (2021). Investigating lesson study model within the scope of professional development in terms of pre-service teachers. International Online Journal of Educational Sciences, 13(5), 1388-1408.

Bandura, A. (1977). Self-efficacy: toward a unifying theory of behavioral change. Psychological review, 84(2), 191-215. doi: 10.1037/0033-295X.84.2.191

Chassels, C., \& Melville, W. (2009). Collaborative, reflective, and iterative Japanese lesson study in an initial teacher education program: Benefits and challenges. Canadian Journal of Education, 32(4), 734-763. Retrieved from https://www.jstor.org/stable/canajeducrevucan.32.4.734?seq=1

Estrella, S., Zakaryan, D., Olfos, R., \& Espinoza, G. (2020). How teachers learn to maintain the cognitive demand of tasks through Lesson Study. Journal of Mathematics Teacher Education, 23(3), 293-310. Retrieved from https://link.springer.com/article/10.1007/s10857-018-09423-y

Frykholm, J. A. (1998). Beyond supervision: Learning to teach mathematics in community. Teaching and Teacher Education, 14(3), 305-322. doi: 10.1016/S0742051X(97)00043-7

González, G., \& Deal, J. T. (2019). Using a creativity framework to promote teacher learning in lesson study. Thinking skills and creativity, 32, 114-128. doi: 10.1016/j.tsc.2017.05.002

Greenhill, V. (2010). 21st Century Knowledge and Skills in Educator Preparation. Partnership for 21 st century skills. https://files.eric.ed.gov/fulltext/ED519336.pdf

Hamarat, E. (2019). 21. Yüzyıl becerileri odağında Türkiye'nin eğitim Politikaları [Education policies of Turkey in the focus of $21^{\text {st }}$ century skills]. İstanbul: Seta Yayinc1lik.

Lamb, P. (2015). Peer learning between pre-service teachers: embracing lesson study. International Journal for Lesson and Learning Studies, 4(4), 343-361. Doi: 10.1108/IJLLS-03-2015-0012

Lampley, S. A., Gardner, G. E., \& Barlow, A. T. (2018). Exploring pedagogical content knowledge of biology graduate teaching assistants through their participation in lesson study. Teaching in Higher Education, 23(4), 468-487. doi: 10.1080/13562517.2017.1414786

Lewis, C. (2000). Lesson study: The core of Japanese professional development. Paper presented at the American Educational Research Association (2000 Annual Meeting), New Orleans, LA. Retrieved from https://files.eric.ed.gov/fulltext/ED444972.pdf

Mills, A. J., Durepos, G., \& Wiebe, E. (2010). Encyclopedia of case study research. London, England: Sage. doi: 10.4135/9781412957397

Murata, A., \& Pothen, B. E. (2011). Lesson study in preservice elementary mathematics methods courses: Connecting emerging practice and understanding. In Lesson study 
research and practice in mathematics education (pp. 103-116). Springer, Dordrecht. doi: 10.1007/978-90-481-9941-9_8

OECD, (2015). PISA 2015 results in focus. Retreived from https://www.oecd.org/pisa/pisa2015-results-in-focus.pdf

Obara, S., \& Bikai, N. (2019). Promoting math teacher active learning with the lesson study approach. International Journal for Lesson and Learning Studie, 8(2), 135-148. Doi: 10.1108/IJLLS-11-2018-0088

Ong, E. G., Lim, C. S., \& Ghazali, M. (2013). Enhancing communication skills in mathematics teachers through the lesson study collaboration: A pilot study. SpringerPlus 5, 1590. doi: 10.1186/s40064-016-3215-0

Onwuegbuzie, A. J., \& Leech, N. L. (2010). Generalization practices in qualitative research: A mixed methods case study. Quality \& Quantity, 44(5), 881-892. doi: 10.1007/s11135009-9241-z

Öztürk, G., \& Aydın, B. (2019). English language teacher education in Turkey: Why do we fail and what policy reforms are needed?. Anadolu Journal of Educational Sciences International, 9(1), 181-213. https://doi.org/10.18039/ajesi.520842

Partnership for 21st Century Learning. (2015). P21 framework definitions. Retrieved from https://eric.ed.gov/?id=ED519462

Patton, M. Q. (2002). Qualitative research and evaluation methods (3rd ed). Thousand Oaks, CA: Sage.

Powney, J., \& Watts, M. (1987). Interviewing in educational research. London: Routledge and Kegan Paul.

Purwanti, E., \& Hatmanto, E. D. (2019). Understanding EFL teachers' beliefs about lesson study and their knowledge development viewed from social cultural theory of Vygotsky. English Language Teaching Educational Journal, 2(2), 50-61. Retrieved from http://journal2.uad.ac.id/index.php/eltej/article/view/1241/pdf_1

Samaranayake, G., Premadasa, K., Amarasinghe, R., \& Paneru, K. (2018). Teacher change through Lesson Study collaboration. International Journal for Lesson and Learning Studie, 7(4), 263-276. doi: 10.1108/IJLLS-12-2017-0055

Skott, C. K., \& Møller, H. (2020). Adaptation of lesson study in a Danish context: Displacements of teachers' work and power relations. Teaching and Teacher Education, 87. doi: 10.1016/j.tate.2019.102945

Stigler, J. W., \& Hiebert, J. (2009). The teaching gap: Best ideas from the world's teachers for improving education in the classroom. New York: Simon and Schuster.

Stigler, J. W., \& Hiebert, J. (2016). Lesson study, improvement, and the importing of cultural routines. ZDM, 48(4), 581-587. doi: 10.1007/s11858-016-0787-7.

Tasker, T. C. (2014). Exploring EFL teacher professional development through lesson study: An activity theoretical approach. (Unpublished doctoral dissertation). Pennsylvania State University, Pennsylvania.

TIMSS (2015). TIMSS 2015 and TIMSS advanced 2015 international results. Retrieved from http://timss2015.org

Villalon, J. J. (2016). Lesson study: Its influence on planning, instruction, and self-confidence of pre-service mathematics teachers. US-China Education Review B, 6(7), 429-439. doi: $10.17265 / 2161-6248 / 2016.07 .003$

Vygotsky, L. (1978). Interaction between learning and development. Readings on the development of children, 23(3), 34-41.

Welsh, E. (2002, May). Dealing with data: Using NVivo in the qualitative data analysis process. In Forum Qualitative Sozialforschung/Forum: Qualitative Social Research, 3(2). 
Retrieved from http://www.qualitativeresearch.net/index.php/fqs/article/view/865/ 1881

Appendix 1. 4Cs checklist Pre-service teacher... Yes No

...is open to new ideas and welcome new experiences.

...tends to exhibit determination and doggedness when working on a project.

...is willing to be critical (and takes criticism) of his/her work.

...implements innovation in his/her activities.

...is capable of developing creative solutions.

...can develop new ideas that are entwined with originality and inventiveness

...demonstrates imagination and curiosity in his/her learning

...works creatively with others.

...can make connections between information and arguments.

... is capable of interpreting information to draw conclusions.

...is capable of reflects critically on learning experiences and processes.

...can solve problems in both a conventional manner and through the use of innovation.

...can make judgments and decisions, based on effectively analysing and

evaluating evidence, arguments, claims and beliefs.

...has flexibility in considering alternatives and opinions. ...is open-minded regarding divergent world views

...respects other's differences and use their different personalities.

...tends to collectively solve problems as a team.

...is aware of the shared responsibility for participation and decision-making.

....shares resources of time, knowledge, and materials

...feels the responsibility for the outcomes, regardless of whether the results

of collaboration are positive or negative.

...can present their ideas articulately.

己 